Original Research Paper

\title{
Kandungan Klorofil-a dan Fikoeritrin Kappaphycus alvarezii Hasil Kultur Jaringan dan dibudidayakan pada Jarak Tanam Berbeda
}

\author{
Nunik Cokrowati ${ }^{1 *}$, Salnida Yuniarti L ${ }^{1}$, Nanda Diniarti ${ }^{1}$, Muhammad Supiandi ${ }^{1}$, Bangun ${ }^{2}$ \\ ${ }^{1}$ Program Studi Budidaya Perairan, Jurusan Perikanan dan Ilmu Kelautan, Fakultas Pertanian, Universitas Mataram. \\ Mataram Nusa Tenggara Barat, Indonesia. \\ ${ }^{2}$ Balai Perikanan Budidaya Laut Lombok-Stasiun Gerupuk, Gerupuk, Lombok Tengah, Nusa Tenggara Barat, Indonesia.
}

\author{
Riwayat artikel \\ Received : 16 April 2020 \\ Revised : 20 April 2020 \\ Accepted : 21 April 2020 \\ Published : 22 April 2020 \\ *Corresponding Author: \\ Nunik Cokrowati \\ Program Studi Budidaya \\ Perairan, Jurusan Perikanan \\ dan Ilmu Kelautan, Fakultas \\ Pertanian, Universitas \\ Mataram. Mataram Nusa \\ Tenggara Barat, Indonesia. \\ Email: \\ nunikcokrowati@unram.ac.id
}

\begin{abstract}
Abstrak: Pertumbuhan Kappaphycus alvaerzii dipengaruhi oleh jumlah klorofil-a, fioeritrin serta faktor kualitas lingkungan perairan. Penelitian ini bertujuan untuk mengetahui pengaruh jarak tanam yang berbeda terhadap kandungan klorofil- $a$ dan fikoeritrin pada Kappaphycus alvarezii hasil kultur jaringan yang dibudidayakan pada patok dasar. Penelitian ini dilakukan di Perairan Pantai Siwak Desa Gerupuk Kecamatan Sengkol Kabupaten Lombok tengah. Budidaya Kappaphycus alvarezii dilakukan selama tiga puluh hari yaitu pada tanggal 10 Maret sampai dengan 9 April 2020 dengan menggunakan metode patok dasar. Rancangan penelitian yang digunakan adalah Rancangan acak lengkap dengan empat perlakuan yaitu perlakuan A (jarak tanam $10 \mathrm{~cm})$, B (jarak tanam $15 \mathrm{~cm}), \mathrm{C}$ (jarak tanam $20 \mathrm{~cm}$ ), D (jarak tanam $25 \mathrm{~cm}$ sebagai kontrol). Bibit Kappaphycus alvarezii yang digunakan adalah hasil kultur jaringan yang telah diadaptasikan di pantai. Pengukuran klorofil- $a$ dan fikoeretrin dilakukan dengan menggunakan spektrofotometri dan selanjutnya data dianalisa secara statistik. Hasil penelitian ini mendapatkan bahwa jarak tanam $25 \mathrm{~cm}$ (kontrol) menghasilkan kandungan klorofil-a tertinggi yaitu 5,4986 mg/l dengan kandungan fikoeritrin $0,0049 \mathrm{mg} / \mathrm{l}$. Kandungan fikoeritrin tertinggi adalah jarak tanam $10 \mathrm{~cm}$ yaitu $0,0057 \mathrm{mg} / \mathrm{l}$ dengan kandungan klorofil- $a$ sebanyak 4,7662 mg/l. Jarak tanam $25 \mathrm{~cm}$ dapat meningkatkan kandungan klorofil- $a$ yang lebih baik karena dengan jarak tanam tersebut memberikan ruang bagi semua bagian thallus rumput laut $K$. alvarezii untuk bisa menerima cahaya matahari yang cukup dan sesuai untuk kebutuhannya. Jarak tanam $10 \mathrm{~cm}$ memberikan kandungan fikoeritrin yang tertinggi, yaitu $0,0057 \mathrm{mg} / \mathrm{l}$ karena terlalu rapatnya jarak ini menyebabkan semakin banyak terbentuknya naungan sehingga mengurangi intensitas cahaya yang masuk ke dalam dinding sel rumput laut. Pada bagian thallus yang sedikit atau tidak menerima cahaya matahari ini diduga terjadi pembentukan fikoeritrin yang lebih banyak sebagai bentuk adaptasi thallus rumput laut pada kondisi tidak mendapatkan cahaya matahari yang optimal. Kesimpulan penelitian ini adalah jarak tanam mempengaruhi kandungan klorofil- $a$ dan fikoeritrin. Jarak tanam yang ideal adalah $25 \mathrm{~cm}$ untuk menghasilkan kandungan klorofila- $a$ yang optimum untuk mendukung pertumbuhan.
\end{abstract}

Kata kunci: Fotosintesis, cahaya matahari, talus, pertumbuhan, unsur hara.

Abstract: The growth of Kappaphycus alvarezii is influenced by the amount of chlorophyll- $a$, phycoerythrin and the quality factors of the aquatic environment. This study aims to determine the effect of different plant spacing on the content of chlorophyll- $a$ and phycoerythrin on Kappaphycus alvarezii tissue culture results that are cultivated on the bottom-off method. This research was conducted in the waters of Siwak Beach, Gerupuk Village, Sengkol District, Central Lombok Regency. Kappaphycus alvarezii cultivation is conducted for thirty days, from March 10 to April 9, 2020, using the bottom-off method. The study design used was a completely randomized design with four treatments, namely treatment A (10 cm spacing), B (15 $\mathrm{cm}$ spacing), C (20 cm spacing), D (25 cm spacing as a control). Kappaphycus alvarezii seeds used are the result of tissue culture that has been adapted on the beach. Measurements of chlorophyll- $a$ and phycoerythrin were carried out using 
spectrophotometry and then the data were analyzed statistically. The results of this study found that the spacing of $25 \mathrm{~cm}$ (control) resulted in the highest chlorophyll- $a$ content of $5.4986 \mathrm{mg} / \mathrm{l}$ with a phycoerythrin content of $0.0049 \mathrm{mg} / \mathrm{l}$. The highest content of phicoeritrin is a spacing of $10 \mathrm{~cm}$ which is $0.0057 \mathrm{mg} / \mathrm{l}$ with a chlorophyll$a$ content of $4.7662 \mathrm{mg} / \mathrm{l}$. A spacing of $25 \mathrm{~cm}$ can increase the chlorophyll- $a$ content better because the spacing gives space for all parts of the Kappaphycus alvarezii thallus to be able to receive sufficient sunlight and is suitable for their needs. A spacing of $10 \mathrm{~cm}$ gives the highest content of phycoerythrin, which is $0.0057 \mathrm{mg} / 1$ because of the too-close this distance causes more shading to form and thus reduces the intensity of light entering the seaweed cell wall. On the part of the thallus that receives little or no sunlight, it is thought that the formation of phycoerythrin is more likely to occur as a form of adaptation of the seaweed thallus in conditions that do not get optimal sunlight. This study concludes that the spacing affects the chlorophyll- $a$ and phicoeritrin content. The ideal spacing is $25 \mathrm{~cm}$ to produce the optimum chlorophyll- $a$ content to support growth.

Keywords: Photosynthesis, sunlight, thallus, growth, nutrients

\section{Pendahuluan}

Rumput laut yang dibudidayakan di Pulau Lombok menurut Cokrowati et al., (2017) adalah Kappaphycus alvarezii dan Gracillaria sp. Kappaphycus alvarezii dibudidayakan di beberapa negara untuk kepentingan komersil sebagai penghasil karaginan (Bindu, 2011). Kappaphycus alvarezii merupakan komoditas budidaya yang mudah dibudidayakan, biaya dan modal budidaya dapat dijangkau masyarakat dan waktu panen singkat (Mulyaningrum et al, 2012). Budidaya Kappaphycus alvarezii di pulau Lombok dilakukan di Teluk Gerupuk, Teluk Ekas, pantai Buwun Mas, dan Teluk Seriweh. Metode budidaya yang digunakan oleh pembudidaya disesuaikan dengan kondisi perairan yaitu metode patok dasar, metode longline dan metode rakit apung. Bibit yang digunakan saat ini adalah bibit konvensional dan bibit hasil kultur jaringan. Pemerintah dalam hal ini Kementerian Kelautan dan Perikanan melalui Seaweed Centre Gerupuk yang merupakan unit pelaksana Balai Pengembangan Budidaya Laut Lombok Sekotong menyediakan bibit Kappaphycus alvarezii hasil kultur jaringan. Bibit tersebut diharapkan dapat menggantikan bibit konvensional yang sudah lama dipakai berulang sehingga menyebabkan kualitas bibit menurun. Sulistiani (2014) menjelaskan bahwa bibit yang dihasilkan dari kultur jaringan mempunyai keunggulan yaitu sifat yang identik dengan induknya dan memiliki daya imunitas yang lebih tinggi sehingga lebih tahan terhadap perubahan kondisi lingkungan dan serangan hama dan penyakit.

Penggunaan bibit kultur jaringan masih banyak membutuhkan kajian dan penelitian lanjutan pada saat bibit tersebut dibudidayakan di perairan. Hal tersebut untuk mendukung optimalisasi pertumbuhan dan waktu pemeliharaan yang efektif dan efisien sesuai tujuan kepentingan pemanenan. Kajian tersebut diantaranya adalah kandungan klorofil-a dan fikoeretrin pada Kappaphycus alvarezii karena kedua komponen tersebut terkait dengan pertumbuhan dan karaginan yang akan dihasilkan.

Pertumbuhan Kappaphycus alvaerzii dipengaruhi oleh jumlah klorofil yang merupakan zat hijau daun yang dimiliki oleh tumbuhan. Henley et al., (2012) menerangkan bahwa klorofil terdiri dalam bentuk klorofil $a, b, c, d$ dan $e$, tetapi dalam alga laut yang dapat diisolasi hanya klorofil $a, b$ dan $c$. Klorofil $a$ terdapat pada semua jenis alga, sedangkan pada klorofil $b$ dan $c$ hanya pada golongan tertentu. Klorofil $a$ merupakan salah satu bagian terpenting dalam proses fotosintesis dan dimiliki oleh sebagian besar alga yang hidup di laut. Jumlah klorofil- $a$ juga lebih dominan dibandingkan klorofil $b$ dan $c$. Hal itu juga yang menyebabkan jumlah klorofil $a$ lebih berpengaruh terhadap proses pertumbuhan Kappaphycus alvarezii dibandingkan dengan jumlah klorofil $b$ dan $c$.

Kappaphycus alvarezii membentuk pigmen lain yang disebut sebagai fikoeritrin sebagai bentuk adaptasi untuk antisipasi terhadap keterbatasan cahaya. Fikoeritrin berfungsi sebagai pigmen pelengkap ("acessory pigment"), untuk optimasi penangkapan cahaya matahari dalam perairan. Distribusi alga secara vertikal berkaitan dengan kemampuan baradaptasi dalam membentuk pigmen pelengkap fikoeritrin. Dawes (1981) menjelaskan bahwa fikoeritrin berperan dalam membantu rumput laut menangkap cahaya yang digunakan klorofil-a dalam proses fotosintesis. Pada saat rumput laut kesulitan dalam membentuk pigmen klorofil- $a$, maka rumput laut tersebut akan membentuk fikoeritrin sebagai respon terhadap kondisi tersebut, sehingga energi cahaya yang diserap oleh fikoeritrin selanjutnya diteruskan ke klorofil- $a$, dan 
rumput laut tetap dapat melakukan aktivitas fotosintesis secara optimum.

Kandungan klorofil- $a$ dan fikoeretrin berpengaruh terhadap pertumbuhan Kappaphycus alvarezii. Jika kandungan kedua komponen tersebut maksimal maka pertumbuhan Kappaphycus alvarezii juga akan maksimal karena proses fotosisntesis berlangsung secara maksimal. Sehinnga diperlukan penelitian ini dengan tujuan untuk mengetahui pengaruh jarak tanam yang berbeda terhadap kandungan klorofil- $a$ dan fikoeritrin pada Kappaphycus alvarezii hasil kultur jaringan yang dibudidayakan dengan menggunakan metode patok dasar.

\section{Bahan dan Metode}

\section{Waktu dan Tempat}

Penelitian ini dilakukan di Perairan di Perairan Pantai Siwak Desa Gerupuk Kecamatan Sengkol Kabupaten Lombok tengah. Budidaya Kappaphycus alvarezii dilakukan selama tiga puluh hari pada tanggal 10 Maret sampai dengan 9 April 2020 dengan menggunakan metode patok dasar. Analisa chlorofil-a dan fikoeritrin dilakukan di Laboratorium Balai Perikanan Budidaya Laut Lombok di Sekotong Lombok Barat.

Rancangan penelitian yang digunakan adalah Rancangan acak lengkap dengan empat (4) perlakuan yaitu penanaman Kappaphycus alvarezii dengan jarak tanam berbeda dan diulang sebanyak empat kali. Perlakuan tersebut adalah A (jarak tanam $10 \mathrm{~cm}), \mathrm{B}$ (jarak tanam $15 \mathrm{~cm}), \mathrm{C}$ (jarak tanam $20 \mathrm{~cm}), \mathrm{D}$ (jarak tanam 25 $\mathrm{cm}$ ). Dimana perlakuan D (jarak tanam $25 \mathrm{~cm}$ ) merupakan perlakuan kontrol. Bibit Kappaphycus alvarezii yang digunakan adalah hasil kultur jaringan yang sudah diadaptasikan di perairan pantai. Bibit yang ditanam setiap rumpun sebanyak 50 gram. Kappaphycus alvarezii ditanam pada patok dasar di perairan pantai yang masih tergenang air saat surut terendah. Pengambilan sampel talus Kappaphycus alvarezii dilakukan pada hari ke nol, hari ke tujuh, hari ke lima belas dan hari ke tiga puluh. Pengukuran parameter kualitas air dilakukan setiap tujuh hari selama masa pemeliharaan Kappaphycus alvarezii.

Bahan yang digunakan adalah Kappaphycus alvarezii, tali polyethilen diameter $5 \mathrm{~mm}$, tali polyetilen diameter $10 \mathrm{~mm}$, tali rafia, patok kayu sepanjang $75 \mathrm{~cm}$, plastik, aseton, buffer fosfat. Alat yang digunakan diantaranya palu, pisau, perahu, timbangan kue, penggaris, kamera, tagging, blender, mortal, timbangan analitik, tabung reaksi, sentrifuge, kertas saring, spektrofotometri, temometer air, refraktometer, Disolved Oxigen (DO) meter dan $\mathrm{pH}$ meter.

Analisa klorofil dan fikoeretrin dilakukan dengan cara menghaluskan sampel segar talus Kappaphycus alvarezii, kemudian ditimbang sebanyak 2 gram. Sampel digerus dengan mortal kemudian tambahkan aseton $10 \mathrm{ml}$ (untuk klorofil) dan tambahkan buffer fosfat $10 \mathrm{ml}$ (untuk fikoeretrin). Masukkan larutan dalam tabung reaksi kemudian sentrifuge dan saring. Selanjutnya diukur menggunakan spektrofotometri. Perhitungan klorofil dan fikoeretrin dilakukan dengan formula sebagaimana pada Laboratorium Balai Perikanan Budidaya Laut Lombok (2020):

a. Chlorofil (mg/l) : 11,93 (A664) - 1,93 (A647)

b. Phycoeritrin (mg/l): ((A564-A592)-(A455A592)0,20) $* 0,12$.

Rancangan percobaan yang digunakan adalah Rancangan Acak Lengkap (RAL). Jarak tanam yang berbeda pada budidaya Kappaphycus alvarezii terhadap kandungan klorofil $a$ dan fikoeritrin. Untuk mengetahui apakah jarak tanam memberikan pengaruh terhadap kandungan klorofil-a dan fikoeritrin Kappaphycus alvarezii, maka dilakukan pengujian ANOVA pada taraf signifikan 95\%. Jika terdapat pengaruh, maka dilanjutkan dengan uji lanjut BNT. Pengujian statistik tersebut dilakukan dengan menggunakan program Excel.

\section{Hasil dan Pembahasan}

\section{Kandungan Klorofil- $\boldsymbol{a}$}

Kandungan klorofil- $a$ pada setiap jarak tanam yang berbeda disajikan pada gambar di bawah ini. Jarak tanam $25 \mathrm{~cm}$ (kontrol) menghasilkan kandungan klorofila tertinggi yaitu 5,4986 mg/l. Jarak tanam $25 \mathrm{~cm}$ merupakan jarak tanam yang digunakan oleh pembudidaya pada umumnya. Kandungan klorofil-a urutan kedua adalah pada jarak tanam $10 \mathrm{~cm}$ yaitu 4,7662 $\mathrm{mg} / \mathrm{l}$ kemudian diikuti oleh jarak $20 \mathrm{~cm}$ dengan kandungan klorofil- $a$ sebanyak 4,2745 mg/l. Kandungan klorofil terendah terdapat pada perlakuan jarak tanam 15 cm yaitu 4,1196 mg/l.

\section{Klorofil-a (mg/l)}

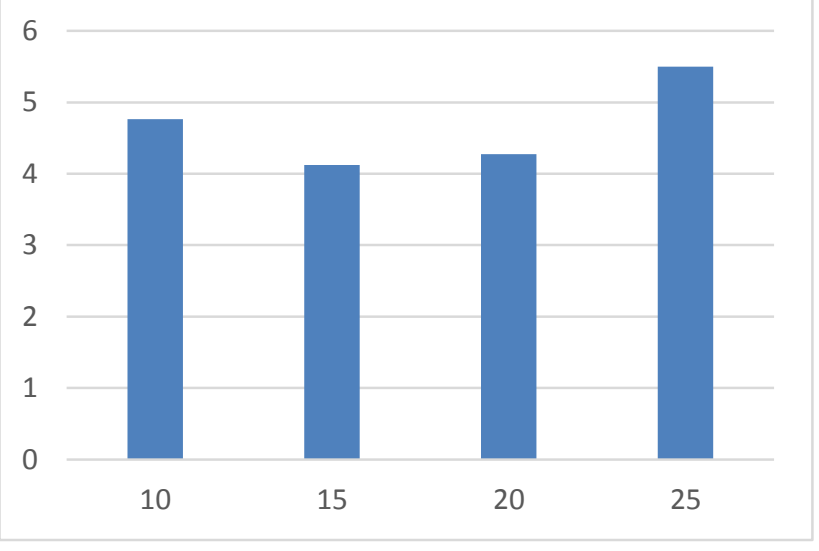

Gambar 1. Grafik kandungan klorofil- $a$ pada masingmasing jarak tanam. 
Hasil analisa ANOVA memperlihatkan bahwa perbedaan jarak tanam memberi pengaruh sangat nyata terhadap kandungan klorofil- $a$, nilai $\mathrm{P}$ adalah 0,00624 berarti $\mathrm{P}<001$. Hasil uji lanjut BNT $(\mathrm{P}<0,05)$ menunjukkan bahwa setiap perbedaan jarak tanam tidak berbeda nyata antar perlakuan terhadap kandungan klorofil-a Kappaphycus alvarezii.

\section{Fikoeretrin}

Kandungan fikoeritrin Kappaphycus alvarezii pada setiap jarak tanam menunjukkan nilai yang sangat berbeda. Kandungan fikoeritrin tertinggi $0,0057 \mathrm{mg} / \mathrm{l}$ terdapat pada perlakuan $10 \mathrm{~cm}$. Urutan kedua adalah jarak tanam $15 \mathrm{~cm}$ yaitu $0,0054 \mathrm{mg} / \mathrm{l}$ selanjutnya diikuti oleh jarak $25 \mathrm{~cm}$ dengan kandungan fikoeritrin sebanyak 0,0049 mg/l. Kandungan fikoeritrin terendah yaitu $0,0035 \mathrm{mg} / \mathrm{l}$ didapatkan pada jarak tanam $20 \mathrm{~cm}$. Berikut ini adalah grafik histogram kandungan fikoeritrin pada setiap jarak tanam yang berbeda.

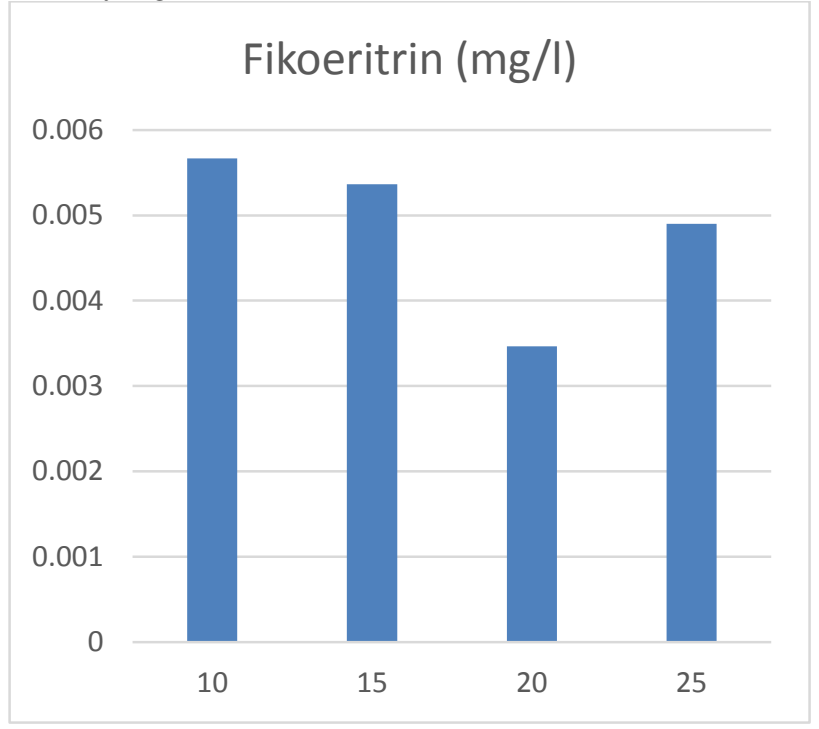

Gambar 2. Grafik kandungan fikoeritrin pada masing masing jarak tanam.

Hasil analisa ANOVA memperlihatkan bahwa perbedaan jarak tanam memberi pengaruh sangat nyata terhadap kandungan fikoeritrin, nilai $\mathrm{P}$ adalah 0,00228 berarti $\mathrm{P}<0,01$. Hasil uji lanjut $\mathrm{BNT} \quad(\mathrm{P}<0,05)$ menunjukkan bahwa setiap perbedaan jarak tanam tidak berbeda nyata antar perlakuan terhadap kandungan fikoeritrin Kappaphycus alvarezii.

\section{Kualitas Air}

Nilai pengukuran parameter sebagaimana tersaji pada tabel berikut ini.
Tabel 1. Nilai Parameter Kualitas air

\begin{tabular}{|c|c|c|c|}
\hline Parameter & Satuan & $\begin{array}{c}\text { Kisaran } \\
\text { Nilai } \\
\end{array}$ & Referensi \\
\hline Suhu & ${ }^{\circ} \mathrm{C}$ & $27-30$ & 26-32 (SNI, 2011) \\
\hline $\begin{array}{l}\text { Oksigen } \\
\text { terlarut }\end{array}$ & ppm & $\begin{array}{l}4,64- \\
5,16-\end{array}$ & 4 (SNI, 2011) \\
\hline $\mathrm{pH}$ & - & $7,9-9$ & 7-8,5 (SNI, 2011) \\
\hline Salinitas & ppt & $31-34$ & 28-34 (SNI, 2011) \\
\hline $\begin{array}{l}\text { Kecepatan } \\
\text { arus }\end{array}$ & $\mathrm{cm} / \mathrm{s}$ & $\begin{array}{c}20- \\
20,49 \\
\end{array}$ & 20-30 (SNI, 2011) \\
\hline $\begin{array}{l}\text { Kedalaman } \\
\text { Air }\end{array}$ & $\mathrm{m}$ & $\begin{array}{c}0,56- \\
1,13\end{array}$ & < $2 \mathrm{~m}$ (SNI, 2011) \\
\hline Phospat & $\mathrm{mg} / \mathrm{l}$ & 0,46 & $>0,1$ (SNI, 2011) \\
\hline Nitrat & $\mathrm{mg} / \mathrm{l}$ & $<0,01$ & $>0,04(\mathrm{SNI}, 2011)$ \\
\hline
\end{tabular}

Nilai parameter kualitas air secara keseluruhan berada pada kisaran yang disyaratkan untuk budidaya Kappaphycus alvarezii sistem patok dasar. Hanya pada nilai Nitrat yaitu $<0,01 \mathrm{mg} / \mathrm{l}$ termasuk rendah jika dibandingkan dengan standar yang ditetapkan SNI yaitu $>0,04 \mathrm{mg} / \mathrm{l}$. Nitrat merupakan unsur hara yang dapat meningkatkan kandungan klorofil- $a$ dann fikoeritin Kappaphycus alvarezii.

\section{Pembahasan}

\section{Kandungan Klorofil- $a$}

Pertumbuhan rumput laut terjadi karena rumput laut melakukan proses respirasi dan fotosintesis serta dukungan dari kualitas air dan unsur hara yang terlarut di dalamnya (Cokrowati et al., 2019). Perkembangan rumput laut dalam kegiatan budidaya tidak hanya dipengaruhi oleh teknik budidaya dan kualitas air yang mendukung tetapi juga dapat berhubungan dengan pigmen fotosintesis, yaitu klorofil- $a$. Jika penyerapan cahaya yang dilakukan klorofil- $a$ mencukupi maka proses fotosintesis akan berlangsung optimal sehingga pertumbuhan rumput laut dapat meningkat. Oleh karena itu, klorofil- $a$ ini menjadi penting bagi pertahanan hidup rumput laut atau untuk berkompetisi dengan organisme lain dalam sebuah habitat tertentu (Ming-Li et al., 2010). Hasil penelitian ini menunjukkan bahwa perlakuan jarak tanam $25 \mathrm{~cm}$ (kontrol) memberikan rata-rata kandungan klorofil- $a$ yang paling tinggi yaitu 5,4986 mg/l (Gambar 1.).

Diduga bahwa pengggunaan jarak tanam $25 \mathrm{~cm}$ (perlakuan D) pada budidaya $K$. alvarezii dengan metode patok dasar dapat meningkatkan kandungan klorofil- $a$ yang lebih baik karena dengan jarak tanam tersebut memberikan ruang bagi semua bagian thallus rumput laut $K$. alvarezii untuk bisa menerima cahaya berupa sinar matahari yang cukup dan sesuai dengan kebutuhannya. Cahaya dari sinar matahari tersebut merupakan sumber energi untuk melakukan proses fotosintesis. Sementara 
peningkatan fotosintesis dapat meningkatkan kemampuan rumput laut untuk memperoleh unsur hara atau nutrien untuk pertumbuhan. Chen and Lee (2012) menyatakan bahwa penetrasi cahaya merupakan salah satu faktor pembatas untuk pertumbuhan rumput laut, apabila cahaya yang diterima berada di bawah tingkat kebutuhan, maka energi yang dihasilkan melalui proses fotosintesa tidak seimbang atau tidak terpenuhi, apabila cahaya yang diterima terus menerus dapat menyebabkan tumbuhan makin lama makin mati. Hal ini juga didukung dengan fungsi klorofil sebagai pelindung alga terhadap radiasi UV yang berlebihan serta melindungi jaringan alga dari stres oksidatif (Yuan, 2007).

Sementara pada perlakuan jarak tanam $15 \mathrm{~cm}$ (perlakuan B) dan $20 \mathrm{~cm}$ (perlakuan C) memberikan ratarata kandungan klorofil- $a$ yang lebih rendah dibandingkan jarak tanam $25 \mathrm{~cm}$ diduga disebabkan karena jarak tanamnya yang semakin rapat sehingga menyebabkan ketika rumput laut $K$. alvarezii bertambah besar maka sebagian thallus saling menutupi thallus yang lainnya. Akibatnya pada bagian thallus yang saling menutupi tersebut membentuk naungan sehingga diduga naungan ini menghalangi penetrasi cahaya matahari yang masuk ke dalam dinding sel rumput laut. Semakin rapat jarak tanamnya maka naungan yang terbentuk semakin banyak dan besar sehingga menurunkan kandungan klorofil- $a$. Hasil penelitian ini menunjukkan bahwa jarak tanam 15 $\mathrm{cm}$ (perlakuan B) memberikan kandungan klorofil- $a$ yang lebih rendah jika dibandingkan perlakuan jarak tanam 20 cm (perlakuan C) (Gambar 1.).

\section{Kandungan Fikoeritrin}

Proses fotosintesis pada rumput laut tidak hanya menggunakan klorofil- $a$ tetapi terdapat pigmen asesoris atau pelengkap, yaitu fikobiliprotein (R-fikosianin, allofikosianin serta fikoeritrin) (Chakdar et al., 2012; Pugalendren et al, 2012). Struktur dan komposisi pigmen ini bermacam-macam yang terdapat pada cyanobacteria, algae merah (Rhodophita), Cryptomonads dan beberapa Pyrrophyceae ((Niu et al., 2006; Guan et al., 2007). Pigmen asesoris/pelengkap yang dianalisa pada penelitian ini adalah pigmen fikoeritrin. Kandungan fikoeritrin pada rumput laut merah seperti $K$. alvarezii ini yang menyebabkan warna agak kemerah merahan pada permukaan thallus. Selain itu fikoeritrin akan membantu klorofil untuk menangkap cahaya pada kondisi intensitas cahaya yang kurang. Pugalendren et al., (2012); Tandeau, (2003); Kawsar et al., (2011) menyatakan bahwa fikoeritrin merupakan protein yang bekerja sebagai pigmen pelengkap pada algae merah dan alga biru-hijau yang berfungsi untuk membantu klorofil-a dalam menyerap cahaya pada proses fotosintesis. Cahaya yang diserap oleh fikoeritrin secara efisiensi dipindahkan ke fikosianin, kemudian ke allofikosianin, diteruskan ke allofikosianin B dan terakhir ke klorofil.
Hasil penelitian ini menunjukkan bahwa perlakuan jarak tanam $10 \mathrm{~cm}$ (perlakuan A) memberikan rata-rata kandungan fikoeritrin yang tertinggi, yaitu $0,0057 \mathrm{mg} / \mathrm{l}$ (Gambar 2.). Terlalu rapatnya jarak tanam pada jarak tanam $10 \mathrm{~cm}$ (perlakuan A) ini menyebabkan semakin banyak terbentuknya naungan sehingga mengurangi intensitas cahaya yang masuk ke dalam dinding sel rumput laut. Pada bagian thallus yang sedikit atau tidak menerima cahaya matahari ini diduga terjadi pembentukan fikoeritrin yang lebih banyak sebagai bentuk adaptasi thallus rumput laut pada kondisi tidak mendapatkan cahaya matahari yang optimal. Sementara itu pada perlakuan jarak tanam yang lebih besar, yaitu 25 $\mathrm{cm}$ (perlakuan D) menyebabkan kandungan fikoeritrin yang lebih rendah dibandingkan jarak tanam $10 \mathrm{~cm}$ (perlakuan A) dan $15 \mathrm{~cm}$ (perlakuan B). Hal ini disebabkan karena kandungan klorofil-a pada jarak tanam $25 \mathrm{~cm}$ (perlakuan D) lebih banyak digunakan untuk penyerapan cahaya bagi proses fotosintesis.

Faktor lain yang diduga mempengaruhui kandungan klorofil- $a$ dan fikoeritrin pada rumput laut adalah adalah unsur hara, terutama nitrogen $(\mathrm{N})$ yang merupakan unsur yang dibutuhkan dalam pembentukan asam amino klorofil. Kim et al., (2007) menyatakan bahwa sintesis klorofil-a dan phycoerythrin memerlukan N. Sintesis klorofil dapat mengalami kegagalan jika tumbuhan kekurangan senyawa dasar sintesis klorofil, kekurangan $\mathrm{N}$ sebagai unsur pembentuk asam amino klorofil dan kekurangan mineral tertentu sebagai pemicu / aktivator enzim pengkatalis biosintesis klorofil (Gogorcena et al., 2001). Nitrogen dapat diperoleh rumput laut melalui unsur-unsur hara yang terlarut dalam perairan. Unsur-unsur hara terlarut ini akan masuk melalui dinding sel rumput laut secara difusi dan osmosis. Diduga bahwa jarak tanam yang terlalu rapat menyebabkan persaingan unsur hara termasuk nitrogen antar thalus rumput laut akan semakin tinggi karena populasi thalus per luasan area budidaya akan lebih banyak dibandingkan perlakuan jarak tanam yang lebih lebar. Hal ini tentu saja akan mempengaruhi pembentukan klorofil- $a$ dan fikoeritrin. Oleh karena itu perlakuan jarak tanam $25 \mathrm{~cm}$ (perlakuan D) dapat memberikan ruang bagi thalus rumput laut untuk mendapatkan sinar matahari dan unsur hara (Nitrogen) yang lebih baik dan mencukupi dalam keseimbangan pembentukan klorofil- $a$ dan fikoeritrin sehingga dapat memberikan perkembangan rumput laut yang lebih baik selama masa budidaya. Beberapa hasil penelitian sebelumnya tentang pengkayaan unsur hara pada media pertumbuhan rumput laut baik yang dibudidaya di perairan maupun melalui kultur jaringan juga menunjukkan bahwa penambahan unsur $\mathrm{N}$ dan $\mathrm{P}$ pada media pertumbuhan dapat meningkatkan kandungan klorofil- $a$ dan pertumbuhan rumput laut (Liu et al. 2000 ; Kim et al., 2007 ; Lumbessy et al., 2018). 


\section{Kesimpulan}

Jarak tanam yang berbeda memberikan pengaruh terhadap kandungan klorofil-a dan fikoeritrin pada Kappaphycus alvarezii hasil kultur jaringan. Pada penelitian ini, jarak tanam $25 \mathrm{~cm}$ menghasilkan kandungan klorofil- $a$ yang paling tinggi yaitu 5,4986 mg/l dan kandungan fikoeritrin tertinggi $0,0057 \mathrm{mg} / \mathrm{l}$ terdapat pada jarak tanam $10 \mathrm{~cm}$.

\section{Ucapan terima kasih}

Ucapan terima kasih disampaikan kepada Balai Perikanan Budidaya Laut Lombok Sekotong Nusa Tenggara Barat yang telah membantu pelaksanaan penelitian ini.

\section{Daftar Pustaka}

Badan Standarisasi Nasional (2001). Produksi Bibit Rumput Laut Kotoni (Eucheuma cottonii) Bagian1: Metode Lepas Dasar. BSN. Jakarta. http://kkp.go.id/an-component/media/uploadgambarpendukung/DIT\%20PERBENIHAN/SNI\%20Perb enihan/SNI\%20Bibit\%20Rumput\%20Laut\%20Co toni/18671_SNI\%207673.1-2011\%20(LKmetode\%20lepas\%20dasar)_web.pdf

Bindu, M.S. \& Ira, A.L. (2011). The Commercial Red Seaweed Kappaphycus alvarezii-an Overview on Farming and Environment. Journal of Applied Phycology. 23:789-796.

DOI 10.1007/s10811-010-9570-2.

Chen, Y. C. \& M. C. Lee (2012). Double-Power DoubleHeterostucture Light-Emitting Diodes in Microalgae, Spirulina platensis and Nannochloropsis oculata Cultures. Journal of Marine Science and Technology, 20(2): 233-236. https://pdfs.semanticscholar.org/81bc/a245c7aa84 0e7cb07469d650b2a7f4716a74.pdf

Chakdar, H., \& S. Pabbi (2012). Extraction and Purification of Phycoerythrin From Anabaena variabilis (CCC421). Phykos. 42 (1): 25-31. https://www.semanticscholar.org/paper/Extractio n-and-purification-of-Phycoerycthrin-fromChakdar-

Pabbi/649db230c9e716cd03ccb2e39cc2eda14e96 $\underline{\mathrm{a} 0 \mathrm{e} 8}$

Cokrowati, N., Dewi, N.S. \& Rina, K. (2017). Growth Performance of Eucheuma cottonii by Immersing in Several Macroalgae Extract. Jurnal
Aquacultura Indonesiana. 18(1): 26-29. ISSN 2477-69-39.

DOI: http://dx.org./10.21534/ai.v/8i/.72. https://aquasiana.org/index.php/ai/article/view/72/ $\underline{95}$

Cokrowati, N. \& Nanda, D. (2019). Komponen Sargassum aquifolium Sebagai Hormon Pemicu Tumbuh untuk Eucheuma cottonii. Jurnal Biologi Tropis. Volume 19 Nomor 2. Program Studi Pendidikan Biologi PMIPA FKIP. Universitas Mataram. DOI: 10.29303/jbt.v19i2.1107

Dawes, C.J. (1981). Marine Botany. A WileyInternational Sccience Publication. United States. https://www.wiley.com/enus/Marine+Botany $\% 2 \mathrm{C}+2 \mathrm{nd}+$ Edition-p9780471192084

Guan X., Qin S., Zhao F., Zhang X. \& X. Tang (2007). Phycobilisomes Linker Family in Cyanobacterial Genomest: Divergence and Evolution. International Journal Biology Science. 3: 343-355. DOI: $10.7150 /$ ijbs. 3.434

Henley, D. \& Felix, L.F. (2012). Physiological and Photomorphogenic Effect of Light on Marine Macrophytes. Seaweed Biology, Ecological Studies. Springer. B-7. DOI: 10.1016/j.aquabot.2003.11.004

Kim, J. K., G. P. Kreamer, C. D. Neefus, I. K. Chung \& C. Yarish (2007). Effect of Temperature and Ammonium on Growth, Pigment Production and Nitrogen Uptake by Four Species of Porphyra (Bangiales, Rhodophyta) Native to The New England Coast. Journal of Applied Phycology, 19: 431-440. DOI: 10.1007/s10811-006-9150-7

Kawsar S., Yuki F., Ryo M., Hidetaro Y. \& Yasuhiro O. (2011). Protein R-phycoerythrin from Marine Red Alga Amphiroa anceps: Extraction, Purification and Characterization. Phytologia Balcanica. 17(3):347-354. https://pdfs.semanticscholar.org/64db/61287ab64 acbbd6a52bdab653b3b42a357a6.pdf.

Liu, J.W., Dong, S.L., Liu, X.Y. \& Ma, S. (2000). Responses of The Macroalga Gracilaria tenuistipitata var.liui (Rhodophyta) to Iron Stress. Journal of Applied Phycology 12, 605-612. https://link.springer.com/article/10.1023/A:10265 23213818 
Lumbessy, S. Y., Andayani, S., Nursyam, H. \& Firdaus, M. (2018). Concentration of Liquid Pes Media on The Growth and Photosynthetic Pigments of Seaweeds Cotonii Propagule (Kappaphycus alvarezii Doty) Through Tissue Culture. Russian Journal of Agricultural and Socio-Economic $\begin{array}{lllll}\text { Sciences. } & 3(75): & 133 & - & 144 .\end{array}$ https://doi.org/10.18551/rjoas.2018-03.15

Laboratorium Balai Perikanan Budidaya Laut Lombok (2020). Prosedur Analisa Klorofil. Balai Budidaya Pengembangan Budidaya Laut Lombok. Sekotong Lombok Barat Nusa Tenggara Barat.https://kkp.go.id/djpb/bpbllombok/artikel/1 3972-sejarah-bpbl-lombok

Ming-Li, T., W. L. Chu \& S. M. Phang (2010). Effect of Temperature Change on Physiology and Biochemistry of Algae: A Review. Malaysian Journal of Science, 29 (2) : 82-97. DOI: $10.22452 / \mathrm{mj}$ s.vol29no2.1.

Mulyaningrum, S. R. H., Happy, N., Yenny, R. \& A. Parenrengi (2012). Regenerasi Filamen Kalus Rumput Laut Kappaphycus alvarezii dengan Formulasi Zat Pengatur Tumbuh yang Berbeda. Jurnal Penelitian Perikanan. 1(1):52-60. https://jpp.ub.ac.id/index.php/jpp/article/view/118

Niu Jian-Feng, Guang-ce W. \& Cheng-Kui T. (2006). Method for Large-Scale Isolation and Purification of R-phycoerythrin from Red Polysiphonia urceolata Grev. Protein Expression and Purification. 49:23-31.

DOI: $10.1016 /$ j.pep.2006.02.001

Pugalendren S., B. Sarangam \& R. Rengasamy (2012). Extraction of R-Phycoerythrin from Kappaphycus alvarezii (Doty) Doty ex Silva and Analyses of its Physico-Chemical Properties. Youth Education and Research Trust (YERT), 1(7) : 407-411. http://jairjp.com/DECEMBER/12\%20SANGEET HA.pdf

Sulistiani, E. \& Samsul, A.Y. (2014). Kultur Jaringan Rumput Laut Kotoni (Kappaphycus alvarezii). Seameo Biotrop. Bogor.

http://sl.biotrop.org/index.php?option=com_conte nt\&view=article \&id=149\&Itemid=141

Tandeau, Nicole. (2003). Phycobiliprotein and Phycobilisome: The Early Observations. Kluwer Academic Publisher. Netherland. Photosynthesis Research.76:197-205.
https://link.springer.com/article/10.1023/A:10249 54911473 